\title{
Relationships between Human Resource Manager-related Factors and Practice of Strategic Human Resource Management in Sri Lankan Listed Firms
}

\author{
T. L. Sajeewanie \\ And \\ H.H.D.N.P.Opatha
}

\begin{abstract}
The objectives of this research paper were to investigate whether competency, education, experience, age and hierarchical level of human resource manager of the listed firms relate to the practice of SHRM of those firms; and to investigate whether these factors have a significant joint impact on the practice of SHRM of listed companies in Sri Lanka. A research framework consisting of five independent variables and one dependent variable was developed and six hypotheses were formulated using deductive approach. The study was conducted relating to all Sri Lankan listed firms numbering 242. Purpose of the study, type of investigation, extent of researcher interference with the study, study setting, unit of analysis and time horizon were hypotheses testing, noncausal, minimal, noncontrived, individual and cross-sectional respectively. Measures of the study had possessed sufficient validity and reliability. The structured questionnaire was administered to cover all the firms and head of human resource department worked as the respondents on behalf of the firms. 161 human resource heads responded making a response rate of 66.52 per cent. Data exploration ensured the normality and linearity assumptions being not violated. The results of the study showed significant and positive relationships between the independent variables, i.e., competence, education, experience, and hierarchical level of human resource managers and the dependent variable, i.e., practice of SHRM. However, no significant relationship was found between age of human resource manager and practice of SHRM. Multivariate analysis revealed that combined influence of competency, education, experience, age, and hierarchical level of human resource manager on the perceived practice of SHRM within a firm was significant. Findings of the study will be important on practical grounds. Important implications of the findings of the study are that a firm should hire and retain a person as the Head of HRM who should possess a high competence of HRM, higher formal education of HRM, and more experience in HRM in order to establish a serious practice of SHRM, and also the Head of HRM is to be appointed as a member of the Top Management of the firm.
\end{abstract}

Key words: Competency, Head of Human Resource Management, Hierarchical Level, Strategic Human Resource Management

\section{Introduction}

Human Resource Management (HRM) is being increasingly viewed as a source of competitive advantage implying a serious strategic aspect of Business Management. 
Being a developing country Sri Lanka badly needs to practice right HRM in order to accomplish her primary goal, i.e., achieving Higher Standard of Living for its citizens. The field of HRM has undergone tremendous changes and growth over the past 200 years (Butler et.al, 1991). Broadly HRM has gone through several stages of the development (from Welfare during 1900s through Personnel Administration during 1940s, Personnel Management-the developing phase during 1950s, Personnel Management-the mature phase during early late 1960s \& 70s to HRM/ Strategic HRM during 1980s \&90s) (Opatha, 1997). It is viewed as a change or development driven by fundamental environmental changes (particularly in product market conditions), which were not capable of being adequately responded to by the traditional concerns, orientations and power of personnel management function (Beaumont, 1992). In the past few years, the roles of HR professionals were often viewed in terms of transition from operational to strategic, qualitative to quantitative, policing to partnering, short term to long term, administrative to consultative, functional oriented to business oriented, etc. (Ulrich, 1997). It has been generally observed that there is a considerable number of Sri Lankan organizations that do not practice so called Strategic Human Resource Management (SHRM). Discussions with several practicing human resource managers revealed that yet SHRM has not been practiced significantly due to several factors.

Factors affecting the practice of SHRM in an organization can be identified in two categories: external factors and internal factors. There are number of internal factors affecting the practice of SHRM. According to Budhwar (2000), the general HRM policies and practices (such as selection, development, performance evaluation) are determined by a set of traditional contingent variables (such as age, nature and size of the organization). According to Khatri (1999) the four most important factors for managing HRM strategically are business strategy, organizational culture, competency levels of HR managers, and presence of HR strategy.

External factors affecting the practice of SHRM may include Social, Cultural, Political and Economic factors. Changing economic conditions directly influence all operations of any organization, including its human resource activities. Also the human resource laws and regulations of governments have become increasingly important to employees (Milkovich and Boudeau, 2000). According to Gratton et al (1999) the significance of environmental and contextual factors has been long acknowledged in shaping human resource strategies, and in the ability of the company to realize these strategies. The growth of the concept of a strategic approach to managing people can be attributed to rapid environmental changes that have taken place over the last two decades. These environmental influences operate at a general level, and at a more specialized level concerned with the organization's own significant environment.

As far as this research paper is concerned, only factors relating to Human Resource Manager (Head of the Department of Human Resources) in an organization, i.e., competency, education, experience, age and hierarchical level were considered based on the assumption that Human Resource Manager is a major party in practicing right HRM and particularly SHRM within the organization. Principle of parsimony and researchers' interest too influenced on selecting these human resource manager-related factors. Organizations for the study were listed firms in Sri Lanka. Research based Sri Lankan 
literature reveals a gap in the empirical knowledge available about testing the relationships between practice of SHRM and human resource manager-related factors such as competency, education, experience, age and hierarchical level. This paper focuses on addressing the following six specific research questions:

1. Is competency of human resource manager positively related to the practice of SHRM?

2. Is education of human resource manager positively related to the practice of SHRM?

3. Is experience of human resource manager positively related to the practice of SHRM?

4. Is age of human resource manager positively related to the practice of SHRM?

5. Is hierarchical level of human resource manager positvely related to the practice of SHRM?

6. Do competency, education, experience, age and hierarchical level of human resource manager jointly and significantly affect the practice of SHRM?

The objectives of the paper are to investigate whether competency, education, experience, age and hierarchical level of human resource manager of the listed firms relate to the practice of SHRM of those firms; and to investigate whether these factors have a significant joint impact on the practice of SHRM of listed companies in Sri Lanka.

\section{Research Framework}

Practice of SHRM refers to human resource manager's perceived degree of application of SHRM by the particular firm. It seems that there is diversity in the literature over the meaning of "Strategic Human Resource Management Practice" (Boxall and Purcell, 2000). According to Baker (1999), SHRM Practice has number of key features including the internal integration of personnel policies and their external integration with overall strategy and line management responsibility for HR implementation. As per Wan and Tung (2005) the practice of SHRM is the degree of participation in core decision making and partnership played by HRM departments and the specificity and formality that HRM departments require in planning and implementation, all of which are designed to ensure that firm' human capital contributes to achieving firm's business goals. Khatri (1999) defined the concept of practice of SHRM as managing the human factor as a competitive tool. In general, the goal of strategic human resource management is the effective application of human resources to meet organizations' strategic requirements and objectives (Greer, 2003). Budhwar (2000) has identified the main features of practice of SHRM as the practices of integration of HRM into the corporate strategy and devolvement of responsibility for HRM to line managers. Viewing from the above, SHRM is linking HRM with business needs. It is about integration. The term 'integration' stresses three major themes. The first is that HRM should be fully integrated with the strategy and the strategic needs of the organization. The second theme is the coherence of HRM policies within themselves and with other areas of policy. Third theme is the involvement of line managers in managing people at work. For this research paper, following working definition, adapting from Budhwar (2000) was used with regard to the variable of the practice of SHRM: 
"The practices of integration of HRM into the business/corporate strategy and devolvement of HRM to line managers as perceived by the human resource manager of the particular firm." The working definition comprises of the two of the three themes mentioned above. As many scholars have focused on these two aspects, and relatively lesser popularity of the concept of SHRM in Sri Lanka, they were perceived as reflective of the realities of the practice of SHRM in Sri Lankan listed firms in an adequate way.

Competency of Human Resource Manager refers to level of knowledge and skills in HRM, as self rated by the human resource manager in the particular firm. Working definition of competency of human resource manager was: 'self assessment on knowledge of human resource management, the ability to add value to the business and the ability to manage change'. Competency of human resource manager has a major influence on the level of integration between HR management and organizational strategy (Buller, 1988). Golden and Ramanujam (1985) commented that the demonstration of expertise by HR managers resulted in a significant uplift of HR stature and also tightened the HR management and strategy linkage. Competencies of HR managers are significant for participating of the HR function in senior executive decision-making (Zhu et al, 2005). According to Khatri (1999) choosing the right HR managers is important to the strategic management of the HR function. If HR professionals do not have the right HRM knowledge and skills, and are not able to think strategically, the HR function would be relegated to a supportive/secondary role. There is a widespread consensus that HR professionals need to know their organization's business thoroughly-not only in terms of people, but also in terms of the economic, financial, environmental, and technological forces affecting it. Rather than playing a staff role, they should become internal consultants known for their expertise and ability to help solve the HR problems faced by line managers (Mejia et al, 2003). Also Khatri (1999) has pointed out that one of the reasons why HR executives are not invited to the strategic planning table is that they are unable to display the required competencies. Hence following hypothesis was suggested to be tested:

Hypothesis 1: Competency of human resource manager of the firm has a positive relationship with practice of SHRM.

Education is the knowledge or training that a person has gained through formal and systematic study (Collins Birmingham University International Language Database English Dictionary, 1987, p.450). For this study purpose, education of human resource manager was defined as the qualifications that head of HRM has secured from school/college/universities/other institutes. According to Zupan and Kase (2005), one of the reasons why HRM in general and Strategic HRM in particular are not better developed, is poor education of HR managers. They also reveal that less than half of HR managers have more than a high school education and most received little or no HR training during their formal education and not much thereafter. Due to this reason HR managers are rarely involved in the process of formulating business strategy. Education is either significantly related to or is a strong predictor of practice of SHRM (Fogarty, 1994). Hence following hypothesis was formulated in this regard: 
Hypothesis 2: Education of human resource manager of the firm and practice of SHRM are significantly and positively related.

Experience in the field of HRM is very important for HR Managers. It was defined as number of years of working in HRM related job/s. It is also very typical that HR managers have little work experience outside the HR function in the company, which leaves them with limited business knowledge (Zupan and Kase, 2005). Specially the experience in the field of HRM is very important for their participation in the strategic level meetings in the organizations. The more experienced is the human resource manager the more application of SHRM will be. Thus, the relevant experience of the Head of the HRM is likely to have a positive relationship with Practice of SHRM. The third hypothesis is below.

Hypothesis 3: Experience of human resource manager of the firm is positively related to practice of SHRM.

Age is the length of time that one has existed or the duration of life (American Heritage Dictionary of the English Language, 2000). According to Kossek and Lobel (2001) age of an employee has an impact on their contribution to the organization. That is being too young is detrimental to performance because one does not have the necessary knowledge and experience. Age as an independent variable is either significantly related to or is a strong predictor of SHRM Practice (Fogarty, 1994, as in Bhatnagar and Sharma, 2004). On the other hand, it is often assumed that being too old is also detrimental, as ageing [Sick] is believed to be associated with becoming slow and forgetful. Based on the above next hypothesis for the study is as follows:

Hypothesis 4: Age of human resource manager of the firm has a positive relationship with practice of SHRM.

Hierarchical level of the Head of the HRM is the status and role of human resource manager (Zupan and Kase, 2005). It was defined nominally as the level to which the Head of HRM belongs (whether top, middle or lower level of the organizational hierarchy). In most research studies hierarchical level was found to be a significant background variable (Bhatnahar and Sharma, 2004). The status and role of HR manager are significantly related to the practice of SHRM (Zupan and Kase, 2005). According to Budhwar (2000) the practice of SHRM in any organization is known to have a direct impact on the role of personnel specialists. If human resource manager plays a top-level role in the organization then he or she automatically joins when taking the strategic level decisions. If human resource manager is a member of the Board of Directors or top management team, it is more likely that the practice of SHRM gets better. Thus the $5^{\text {th }}$ hypothesis is as follows:

Hypothesis 5: Hierarchical level of the human resource manager of the firm and the practice of SHRM are positively related. 
Combined influence of the above variables on the perceived practice of SHRM refers to simultaneous effect of the five human resource manager-related variables on the practice of SHRM. Competency, education, experience, age and hierarchical level of human resource manager were hypothesised as independent variables that positively relate to the perceived practice of SHRM. Hence it is argued that these five human resource managerrelated variables will have a significant joint impact on the perceived practice of SHRM. Based on this argument the sixth hypothesis for the study is as follows:

Hypothesis 6: Competency, education, experience, age and hierarchical level of human resource manager together will significantly explain the variance in the perceived practice of SHRM.

Practice of SHRM is labeled as the dependent variable of this study as it is the variable of primary interest of the researchers. Competency, education, experience, age and hierarchical level of human resource manager are labeled as independent variables as they are assumed to have influences on the practice of SHRM. Figure 1 depicts the schematic diagram of the research framework of this study.

\section{Figure: 1 Schematic Diagram of the Research Framework}

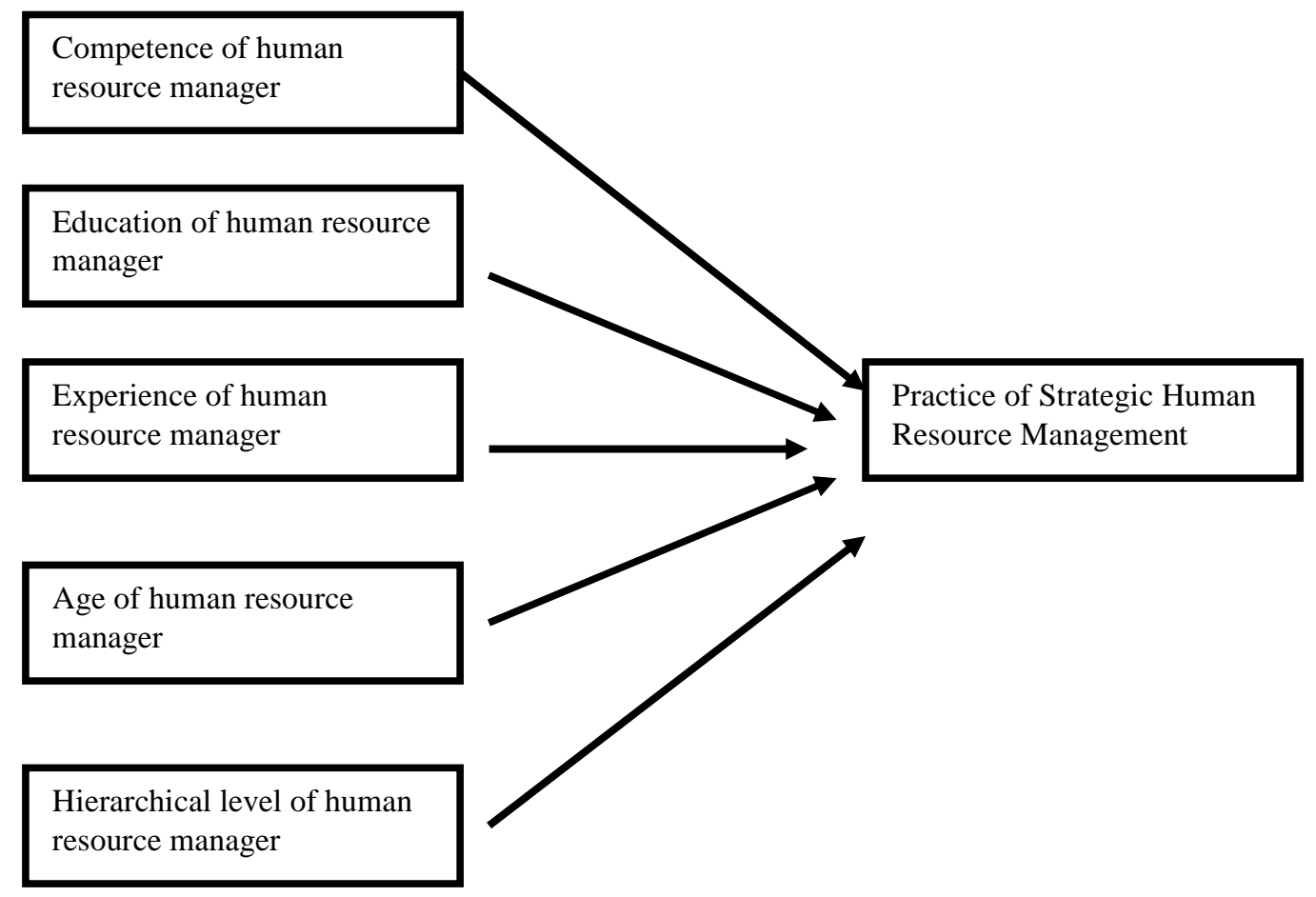




\section{Study Design}

\section{Method}

The researchers were interested in investigating whether competency, education, experience, age and hierarchical level of human resource manager relate to practice of SHRM of listed firms and whether these five variables have a significant joint impact on the practice of SHRM of those firms, rather than establishing definite cause $\rightarrow$ effect relationships among the variables. Hence, the type of investigation of this study is correlational rather than causal. Nature of the study was analytical or hypotheses testing as this study attempted to analyse the relationships between the dependent variable (practice of SHRM) and the independent variables. Time horizon of the study was crosssectional due to the reason that the data for this study were collected at a single point in time (Sekaran, 1999; Zikmund, 2000). When the main focus of the study was considered 'cross-sectional' rather than 'longitudinal' was an appropriate strategy. For the purpose of collection of primary data on which this study was based largely in order to achieve objectives of the study, a self-administered questionnaire was used. Hence the researcher interference on normal flow of events was minimal.

The list of population was obtained from the handbook of Colombo Stock Exchange that is a company liaisoned by the Securities and Exchange Commission to operate as a Stock Exchange in Sri Lanka. The Exchange has 242 companies listed with a market capitalization of approximately 262 billion rupees. The companies listed on the Exchange have been categorized under 20 business sectors such as Bank, Finance and Insurance, Beverages, Food Tobacco and so on. For this study the population refers to all listed companies in Sri Lanka. As all the elements of the population (242 companies) were considered for the survey, no sample was involved in this research.

Since the unit of analysis of this study was Head of the Human Resource Management, the data were collected by mailing the questionnaire with a self-addressed envelope. A letter of request and a letter of appreciation were attached to the questionnaire. They consisted with self-introduction of the researchers, the reason for conducting the research and assurance of security of the information given by the respondents and the due recognition for the support given by the respondents. 161 Heads of HRM of the firms responded for the questionnaire and the response rate was 66.52 per cent.

\section{Measures}

Practice of SHRM: Human resource manager's perceived degree of application of SHRM by the particular firm was operationalised into two dimensions i.e., integration and devolvement. Integration referred to the degree to which HRM issues are considered as part of the formulation of the business strategy. The degree to which line managers have involved in HRM practices was referred to as devolvement. Then, each dimension was operationalised into several elements based on the writing of Budhwar, 2000. Annexe 1 (given at the end of the paper) gives dimensions and elements of the variable of practice of SHRM. 22 questions were included in the questionnaire in order to measure the variable of practice of SHRM. The responses to the questions were elicited on a 5-point scale of 'strongly agree, agree, neither agree nor disagree, disagree, and strongly disagree' or 'very high extent, high extent, neutral, low extent, and very low extent'. 
Weights of 5,4,3,2 and 1 were given to these responses taking whether the questions were negative or positive into account. The score of the practice of SHRM from one respondent could fall within the upper and lower limit of 110 and 22 respectively. Between these limits the practice of SHRM was taken in a continuum of which the range of value or the difference of levels was calculated as $(110-22) / 5=17.6$. For the purpose of analysis these values were transformed into new values from 1 to 5 .

Competency of Human Resource Manager: The variable of competency of human resource manager was operationalized into three dimensions such as competency about the HRM, competency about the business and competency about change. Competency about the HRM focused on eleven elements which included human resource planning, recruitment and selection, orientation, training, appraising job performance, pay management, incentives and welfare management, health and safety, managing discipline, grievance handling and union relations. 11 questions were developed with regard to each element and responses were obtained on a 5-point scale of 'very low, low, average, high and very high'. 6 questions and 10 questions were developed with regard to the other two dimensions (competency about the business and competency about managing change). A 5-point scale of 'strongly agree, agree, neither agree nor disagree, disagree, and strongly disagree' was used to elicit the responses to the questions. Weights of 5,4,3,2 and 1 were given to these responses depending on the nature of the questions (negative or positive).

Education of Human Resource Manager: One direct question relating to nature and level of HRM qualifications was framed to measure the variable of education of human resource manager. A 6-point scale of 'Certificate in HRM, Diploma in HRM (less than one year), Diploma in HRM (one year or more), Degree in HRM, Postgraduate Diploma in HRM, and Masters/Postgraduate Degree in HRM'. Interval was the level of measurement of the variable. Points $1,2,3,4,5$ and 6 were given to the levels of the scale respectively.

Experience of Human Resource Manager: This variable was measured through the use of one direct question that was in respect of hand-on experience in the field of HRM possessed by the respondent. A 3-point scale of 'up to 5 years, between 6 and 10 years, and more than 10 years' was developed, and for the purpose of analysis, points 1, 2, and 3 were given to the levels of the scale respectively.

Age of Human Resource Manager: One direct question was framed to measure the variable of age of human resource manager. The question dealt with degree of oldness of the respondent with a 5-point scale of 'below 30 years, between 30 and 39 years, between 40 and 49 years, between 50 and 59 years, and 60 years or over'. Interval was the level of measurement of the variable and points $1,2,3,4$, and 5 were given to the levels of the scale respectively. 
Hierarchical Level of Human Resource Manager: This variable was measured through one direct question. A 3-point scale of 'top level, middle level, and lower level' was utilized and weights of 3,2 , and 1 were given respectively to the levels of the scale. This variable's level of measurement was interval.

\section{Validity and Reliability}

The content validity of the measures was ensured by conceptualization and operationalization of the domains of the variables based on an adequate literature review. The dimensions and element of the variables were delineated carefully after developing the working definitions based on the literature. The instruments were developed with the careful judgement of the researchers. The instruments (with regard to the two constructs namely practice of SHRM and competency of human resource manager) had a high degree of internal consistency reliability (alpha). These evidences support the content validity of the instruments of this study. The construct validity of the variables of this study was ensured as the correlation analysis supported the hypotheses (except one) formulated linking the relationship between practice of SHRM and the independent variables. To measure the external reliability of the questionnaire, which consisted of all the measures for the study (relating to six variables), a test-retest was conducted by using 10 Heads of HRM in Sri Lankan listed companies with a two-week time interval between the two administrations. The coefficient of the test-retest of the questionnaire was 0.890 suggesting that the measures possessed a high external reliability. To measure the interitem consistency reliability the Cronbach's Alpha test was used (results are given in table 1). According to the results of the test there was an adequate degree of internal reliability with regard to the constructs (practice of SHRM and competency of human resource manager).

Table: 1 Cronbach's Alpha Coefficients

\begin{tabular}{|c|l|l|}
\hline No & \multicolumn{1}{|c|}{ Instrument } & Cronbach's Alpha \\
\hline 01 & $\begin{array}{l}\text { Practice of Strategic Human Resource } \\
\text { Management }\end{array}$ & 0.7841 \\
\hline 02 & Competency of Head of HRM & 0.9144 \\
\hline
\end{tabular}

\section{Techniques of Data Analysis}

There were six hypotheses of the study. The Pearson Product-Moment Correlation technique was used for hypotheses from one to five as they were about relationships between two variables. As the sixth hypothesis was about testing a combined impact of the independent variables on the dependent variable the Multiple Regression technique was applied. Exploration of the data for normality and linearity was carried out because the two techniques used for data analysis were parametric tests. The data exploration revealed that assumptions of normality and linearity had been met reasonably.

\section{Results}

As there are five human resource manager-related variables considered for the study, five hypotheses (from $\mathrm{H}_{\mathrm{A}}$ to $\mathrm{H} 5_{\mathrm{A}}$ ) were formulated to test the relationship between each of 
the variables and the practice of SHRM. The aggregate effect of the five human resource manager-related variables on the practice of SHRM was tested by hypothesis $\left(\mathrm{H6}_{\mathrm{A}}\right)$. The hypothesised relationships are shown in table 2 .

Table: 2 Hypotheses (from $\mathrm{H1}_{\mathrm{A}}$ to $\mathrm{H5}_{\mathrm{A}}$ and $\mathrm{H6}_{\mathrm{A}}$ ) of the Study

\begin{tabular}{|l|l|l|}
\hline $\begin{array}{l}\text { No } \\
.\end{array}$ & Hypothesised Relationship & $\mathbf{H i}_{\mathbf{A}}$ \\
\hline 1 & Competence of Human Resource Manager $\rightarrow$ Practice of SHRM & $\mathrm{H} 1_{\mathrm{A}}(+)$ \\
\hline 2 & Education of Human Resource Manager $\rightarrow$ Practice of SHRM & $\mathrm{H} 2_{\mathrm{A}}(+)$ \\
\hline 3 & Experience of Human Resource Manager $\rightarrow$ Practice of SHRM & $\mathrm{H} 3_{\mathrm{A}}(+)$ \\
\hline 4 & Age of Human Resource Manager $\rightarrow$ Practice of SHRM & $\mathrm{H} 4_{\mathrm{A}}(+)$ \\
\hline 5 & $\begin{array}{l}\text { Hierarchical Level of Human Resource Manager } \rightarrow \text { Practice of } \\
\text { SHRM }\end{array}$ & $\mathrm{H} 5_{\mathrm{A}}(+)$ \\
\hline 6 & $\begin{array}{l}\text { Competence, Education, Experience, Age and Hierarchical Level of } \\
\text { Human Resource Manager } \rightarrow \text { Practice of SHRM }\end{array}$ & $\mathrm{H} 6_{\mathrm{A}}$ \\
\hline
\end{tabular}

$\mathrm{Hi}_{\mathrm{A}}$ stands for the alternative hypothesis and + stands for a positive relationship. The five hypotheses (from $\mathrm{H} 1_{\mathrm{A}}$ to $\mathrm{H} 5_{\mathrm{A}}$ ) have been postulated to be directional and positive in nature.

The results of Pearson's Product Moment Correlation that was used to test the null hypotheses for the five hypotheses (from $\mathrm{H} 1_{\mathrm{A}}$ to $\mathrm{H} 5_{\mathrm{A}}$ ) are shown in table 3 . As a 95 percent confident level is desired, the level of significance $(\propto)$ is .05 . One-tailed test was used because all the five hypotheses were bivariate that were concerned with a positive relationship $\left(\mathrm{H}_{\mathrm{A}}>0\right)$. As can be seen, the correlation coefficients of competency, education, experience, and hierarchical level of human resource manager were significant at $p<.01$ and therefore the null hypotheses pertaining to these four variables were rejected. This means that the hypothesised relationship (positive) between each of the four human resource manager-related variables and the practice of SHRM was supported by the data. When the variable of age is concerned, the relevant correlation coefficient (.130) was not significant at 0.05 level. Hence, there is no statistical evidence to substantiate the hypothesis that age of human resource manager of the firm has a positive relationship with practice of SHRM.

Table: 3 Pearson Correlation Coefficients for all Human Resource Manager-related Variables

\begin{tabular}{|l|l|l|l|}
\hline No & Variables & Coefficient & Sig \\
\hline 1 & Competence of Human Resource Manager & .227 & .009 \\
\hline 2 & Education of Human Resource Manager & $.276^{*}$ & .021 \\
\hline 3 & Experience of Human Resource Manager & $.354^{* *}$ & .0005 \\
\hline 4 & Age of Human Resource Manager & .130 & .067 \\
\hline 5 & $\begin{array}{l}\text { Hierarchical Level of Human Resource } \\
\text { Manager }\end{array}$ & $.265^{* *}$ & .028 \\
\hline
\end{tabular}

$* * \mathrm{p}<.0 .01 \quad \mathrm{n}=161$ 
The sixth (final) hypothesis formulated for the study was that competency, education, experience, age and hierarchical level of human resource manager together will significantly explain the variance in the perceived practice of SHRM. The test of this hypothesis leads to accomplish the second objective of this research study, i.e., to investigate whether human resource manager-related factors have a significant joint impact on the practice of SHRM of listed companies in Sri Lanka. The relevant results of the multiple regression are shown in table 4.

Table: 4 Combined Impact of the Five Human Resource Manager-related Variables on Practice of SHRM

\begin{tabular}{|l|l|l|l|l|l|}
\hline $\mathrm{R}$ & $\mathrm{R}$ Square & $\begin{array}{l}\text { Adjusted } \\
\text { R Square }\end{array}$ & $\begin{array}{l}\text { Std.Error of } \\
\text { the Estimate }\end{array}$ & F Value & Sig. F \\
\hline .386 & .149 & .105 & 9.30803 & 3.425 & 0.007 \\
\hline
\end{tabular}

The results show that the multiple regression coefficient $(\mathrm{R})$ of the five human resource manager-related independent variables and the practice of SHRM was .386 and the R Square was .149. R Square is significant at 0.05 as $F$ value is 3.425 with an observed significant value of .007 (which is less than 0.05 ). It indicates that about 15 percent of the variance (R Square) in the practice of SHRM has been significantly explained by the five independent variables together substantiating the alternative hypothesis $\left(\mathrm{H6}_{\mathrm{A}}\right)$. Therefore, there is statistical evidence to reject the null hypothesis that competency, education, experience, age and hierarchical level of human resource manager together will not significantly explain the variance in the perceived practice of SHRM.

\section{Discussion}

Competency of human resource manager was found to be significantly and positively related to the practice of SHRM. It was hypothesized that competency of human resource manager of the firm has a positive relationship with perceived degree of practice of SHRM. This empirical finding confirms the argument of Mejia et al, (2003) that the HRM competency of HR Managers is significant for the practice of SHRM. Also the finding is consistent with the finding of Khatri (1999). The finding confirms that a high level of competency of human resource manager will lead to generate a high practice of SHRM and vice versa. The implication of the finding is that any organization, which wants to enhance the practice of SHRM, has to improve the competency of its Head of HRM or hire a high competent Head of HRM.

A significant positive relationship was found between educational qualification of the Head of HRM and practice of SHRM. It was hypothesized that education qualification of the Head of HRM is positively related to the practice of SHRM. This study found empirical evidence to support the hypothesis. This finding is matched with the finding of Zupan and Kase (2005) that the educational qualifications are important to the practice of Strategic Human Resource Management. Also this is matched with the finding of Budhwar (2000), which the educational qualifications have been found to affect SHRM practices. Thus, it can be concluded that when educational qualifications of Head of 
HRM are at higher level there will be a high level of practice of Strategic Human Resource Management. Implication of the finding is that any organization, that wishes to practice good SHRM, should consider seriously qualifications of Head of HRM.

It was found that there was a positive relationship between the experience of the human resource manager and practice of SHRM. This finding confirms the finding of Zupan and Kase (2005) that the relevant experience of Head of HRM has a positive relationship with practice of Strategic Human Resource Management. Hence it was found that more experience in HRM activities of the Head of HRM leads to high level of practice of SHRM. Implication of the finding is that any organization, that wishes to practice good SHRM, should consider seriously relevant experience of Head of HR Department.

There was no relationship found between the age of the human resource manager and the practice of SHRM. It was hypothesized that the age of the Head of HRM has a positive relationship with the practice of SHRM. This study did not find a sufficient empirical evidence to accept the hypothesis. This finding is not matched with the finding of Budhwar (2000) that age of the Head of the HRM is significantly related to the practice of Strategic Human Resource Management. Also this is not matched with the finding of Kossek and Lobel (2001), that the age of the Head of HRM has been found to affect SHRM practices. As far as this study result is concerned, age of Head of HR and Practice of SHRM are not significantly related in the Sri Lankan context. Thus, being too old or too young has nothing to do with the serious practice of SHRM. Serious HRM expertise, that leads to practice of SHRM, is likely not dependent upon passing years merely. This may be the reason for no relationship. This might be due to that most of the Heads of HR had no proper HR qualifications under study. Or it might be that other factors such as competency, specialized education, and specialized experience determine the practice of SHRM.

Analysis of data relating to $\mathrm{H} 5$ found that there is a positive relationship between hierarchical level of the Head of HRM and the practice of Strategic Human Resource Management. This finding is matched with the finding of Bhatnagar and Sharma (2004) that the hierarchical level was found to be a significant background variable with regard to the practice of Strategic Human Resource Management. Since this finding supports the theoretical explanations, it is suggested that organizations should offer top-level positions for Heads of Human Resource Management department in order to have better practice of SHRM. It has been supported by the data that in order to increase the practice of Strategic Human Resource Management it is needed to increase the hierarchical level of the Head of the HRM. Head of HRM is to be appointed as a member of the top management team of the firm for a serious practice of SHRM within the firm. It necessitates that the Head of HRM is a member of the strategic planning team.

From the multivariate analysis, it was found that Competency, Education, Age, Experience and Hierarchical level significantly and jointly explain the variance of practice of SHRM. It indicates that these five variables give a significant impact of the practice of SHRM within a firm. The implication of this finding is that it is important for a firm to consider human resource manager-related factors such as competency, 
education, experience, age and hierarchical level in order to improve the practice of SHRM. In fact, other variables not considered in this study should be the variables that will account for the unexplained variance in the practice of SHRM.

\section{Conclusion}

Findings derived from the bivariate analysis of the data were that competency, education, experience, and hierarchical level of the Head of HRM of a firm positively and significantly relate to the practice of SHRM of the firm. However, the results of the study did not substantiate the hypothesised positive relationship between the age of human resource manager and the practice of SHRM. Multivariate analysis revealed a significant combined influence of competency, education, experience, age, and hierarchical level of human resource manager on the perceived practice of SHRM within a firm. Important implications of the findings of the study are that a firm, that wants to establish a serious practice of SHRM, should hire and retain a person as the Head of HRM who should possess a high competence of HRM, higher formal education of HRM, and more experience in HRM. Also the Head of HRM should be appointed as a member of the Top Management of the firm.

\section{References}

Alcazar, F.M., Fernandez, P.M.R., and Gardey, G.S. (2005), Strategic human resource management: integrating the universalistic, contingent, configurational and contextual perspectives, International Journal of Human Resource Management, 16(5), pp. 633-659.

Amarasiri, C. (2002, January 13), Digital Approach to meet the modern HR needs, Sunday Observer, p.18.

American Heritage Dictionary of the English Language, (2000).

Anthony, M. (1996), The HR Survivalist, HR Focus, p.19.

Armstrong, M. (2001), Human Resource Management Practice, $8^{\text {th }}$ ed., London: Kogan Page Limited.

Baker, D. (1999), Strategic human resource management: performance, alignment, management, Librarian Career Development, 7(5), pp.51-63.

Basu, D.R. and Miroshnik, V. (1999), Strategic human resource management of Japanese multinationals - a case study of Japanese multinational companies in the UK, Journal of Management Development, 18(9), pp. 714-732.

Beaumont, P.B. (1992), "Annual Review Article; 1991, British Journal of Industrial Relations, V30 (1), pp. 107-125.

Bhatnagar, J. and Sharma, A. (2004), The Four Pillars of the Proposed Strategic HRM Dimensions Model, Indian Journal of Industry Relations, 40(1), pp. 95-113.

Boxall, P. and Purcell, J. (2000), Strategic human resource management: where have we come from and where should we be going?, International Journal of Management Reviews, 2(2), pp. 183-203.

Budhwar, P.S. (2000), Strategic Integration and Devolvement of Human Resource Management in the UK Manufacturing Sector, British Journal of Management, 11, pp.285-302. 
Buller, P. (1988), "Successful partnerships: HR and strategic planning at eight top firms", Organizational Dynamics, Vol.17, pp.27-42.

Butler, J.E., Ferris, G.R. and Napier, N.K. (1991), Strategy and Human Resource Management, Cincinnati: South-Western Publishing.

Caldwell, R.(2003), The Changing Roles of Personnel Managers: Old Ambiguities, New Uncertainties, Journal of Management Studies, 40(4), pp.983-1004.

Change, W.A. and Huang, T. C., (2005), Relationship between strategic human resource management and firm performance: A contingency perspective, International Journal of Manpower, 26(5), pp.434-449.

Cole, G.A. (1993), Personnel Management, (3 $3^{\text {rd }}$ ed.), London: Loader Jackson Printer.

Cole, G.A. (1997), Personnel Management, (4 ${ }^{\text {th }}$ ed.), London: Ashford Colour Press.

Collins Birmingham University International Language Database (Cobuild) English Language Dictionary (1987), London: Collins.

Dennis, D.V. M. L. (2002), Strategic Human Resource Management: Perceptions Among North Carolina County Social Service Professionals, Public Personnel Management, 31(3), pp.1-15.

Dessler, G. (1998), Human Resource Management, (2 ${ }^{\text {nd }}$ ed.), New Delhi: Prentice Hall of India (Pvt.) Ltd.

Dharmasiri, A. (2005), Development of Conceptual Competencies of Sri Lankan Managers, Proceedings of the $2^{\text {nd }}$ International Conference on Business Management, ICBM University of Sri Jayewardenepura, pp.67-81.

Ericksen J. and Dyer L.(2005), Toward a strategic Human Resource Management model of high reliability organizations performance, International Journal of Human Resource Management, 16(6), pp.875-881.

George C.T. and Kornides J.F. (1994), Strategic HR Management is vital, Personnel Journal, 73 (12), p.115-127.

Graham, L., Hailey V. H., Stiles, P., and Truss, C. (2003), Strategic Human Resource Management (SHRM) Linking People to the Firm to achieve best possible results, People and Profits, 14(2), p.36.

Gratton, L., Hope-Hailey, V., Stiles, P. and Truss, C. (1999), "Linking Individual Performance to Business Strategy: The People Process Model", Human Resource Management, 38(1), pp.17-31.

Greer, C.R. (2003), Strategic Human Resource Management: A General Management Approach, 2 Edi, Delhi: Pearson Education Inc.

Harvey, M. and Novicevic, M. M. (2003), Strategic Global Human Resource Management: Its Role in Global Networks, Research and Practice in Human Resource Management, 11(2), pp.32-51.

Heneman, H.G., Schwab, D.P., Fossum, J.A., and Dyer, L.D. (1994), Personnel/Human Resource Management, $\left(4^{\text {th }} e d\right.$.), New Delhi: Universal Book Stall.

Holbeche,L. (2003), Aligning Human Resources and Business Strategy, Indian Journal of Industry Relation, 38(3), pp.375-380.

Jain, P. (2005), A comparative analysis of strategic human resource management (SHRM) issues in an organizational context, Library Review, 54 (3), pp.166-179.

Kearns, P. (2003), Strategic HR is no 'Black Art' but it needs new ideas, Personnel Today, Web site: http://www.personneltoday.com. 
Khatri, N. (1999), Emerging issues in strategic HRM in Singapore, International Journal of Manpower, 20(8), pp.516-529.

Kossek, E.E. and Lobel, S.A.(2001), Human Resource Management. ( $1^{\text {st }}$ ed.), Delhi: Efficient Offset Printers.

Kumar, R. (1999), Research Methodology, Sage Publications India Pvt Ltd, New Delhi.

Lewis, J. (2002), Charting the evolution of strategic HR, Personnel Today,

Lisman, L.M., Chan, M.A. and Shaffer, (2004), In search of sustained competitive advantage: the impact of organizational culture, competitive strategy and human resource management practices on firm performance, International Journal of Human Resource Management, 15(1),pp.17-35.

Mabey, C. , Salaman, G., and Storey, J. (1998), Strategic Human Resource Management, New Delhi.

Massey, R., (1994), Taking a Strategic approach to Human Resource Management, Health Manpower Management, 20(5), pp.27-30.

Mejia, L.G.M., Balkin, D.B. and Cardy, R.L. (2003), Managing Human Resource, $\left(3^{\text {rd }}\right.$ ed), Delhi: Pushp Print Services.

Milkovich, G. T. and Boudreau, J.W. (2000), Human Resource Management, (4 ${ }^{\text {th }}$ ed.). Delhi: Nice Printing Press.

Mondal, T. (2003), From Strategy to Delivery of Business Results, Global HRM.

Nankarvis, A., Compton, R. and Baird, M. (2002), Strategic Human Resource Management, $\left(4^{\text {th }}\right.$ ed). Melbourne: Nelson Thompson Learning.

Opatha, H.H.D.N.P. (2003), Research Methods for Human Resource Management: Questions and Answers. Part 1, Colombo: Author Publication.

Opatha, H.H.D.N.P. and Ismail, Z.B. (2002), An Empirical Investigation of Management - Related Factors Contributing to Labor- Management Relationship in Manufacturing Firms in Sri Lanka, NMMS Journal, January -June, pp.74-85.

Opatha, H.H.N.P. (1997), Strategic HRM as Part of Strategic Management: A Theoretical Perspective, Vidyodaya Journal, 8(1), pp.103-119.

Overell, S., (2002), The Evolution of HRM, Personnel Today, http: www.personnel today.com.

Prasad, L. and Bannerjee, A.M. (1997), Management of Human Resources, $4^{\text {th }}$ ed.), New Delhi: Sterling Publishers Pvt. Ltd.

Rao, T.V. (1991), Reading in Human Resource and development, New Delhi: Oxford and IBH Publishing Co.

Reddy,Y.R.K. (1991), Strategic Approach to Human Resource Management, New Delhi: Wiley Eastern Limited.

Sekaran, U. (2003), Research Methods for Business: A skill-building approach, $\left(4^{\text {th }} \mathrm{ed}\right.$.). New York: John Wiley \& Sons, Inc.

Selmer, J. and Chiu, R. (2004), Required human resource competencies in the future: a framework for developing HR executives in Hong Kong, Journal of World Business, 39, pp.324-336.

Selmer, J. and Chiu, R. (2004), Required Human Resource Competencies in the future: A Framework for developing HR Executives in Hong Kong, Journal of Management, 39, pp.324-336. 
Sett, P.K. (2004), Human Resource Management and Firm Level Restructuring: The South Asian Drama, Research and Practice in Human Resource Management, 12(1), pp.1-33.

Shermon, G. (2003), Managing Knowledge: Competitive Positioning of Human Resources in $21^{\text {st }}$ Century, Global HRM.

Siddique, C.M. (2004), Job Analysis: A Strategic Human Resource Management Practice, International Journal of Human Resource Management, 15(1), pp.219244.

The American Heritage Dictionary of the English language, (2000), 4th Ed.

Truss, G., Gratton, L., Hailey, V. H., McGovern, P., and Stiles, P. (1997), Soft and Hard Models of Human Resource Management, Journal of Management Studies, 34(1), pp.53-73.

Tyson, S. (Eds.) (1995), Strategic Human Resource Management, IPD House, London.

Ulrich, D. (1997), "Measuring human resources: an overview of practice and a prescription for results", Human Resource Management, Vol. 36 No3, pp. 303-20.

Waite, M. (Ed.), (1994), The Little Oxford Dictionary, RekhaPvt., New Delhi.

Web site: htt://www.globalhrm.com/articles/strategic4.htm.

Web site: http://www.globalhrm.com/articles/strategic1.htm.

Web site: http://www.personneltoday.com.

Web site: http:www.personneltoday.com

Wickramasinghe, V. (2005), Human Resource Function in the Strategy Process: A Case for Convergence, Proceedings of $10^{\text {th }}$ International Conference on Sri Lankan Studies,

Wright, P.M. and Mcmahan, G.C. (2005), New models of Strategic HRM in a global context, International Journal of Human Resource Management, 16(6), pp.875881.

Zhu, C. J., Cooper, B., Cieri, H.D., and Dowling, P. J., (2005), A problematic position to a strategic role: human resource management in industrial enterprises in China, International Journal of Human Resource Management, 16 (4), pp.513-531.

Zikmund, W.G. (1997), Business Research Methods, $5^{\text {th }}$ ed, Fort Worth: Harcourt Brace College Publishers.

Zupan, N. and Kase, R. (2005), Strategic human resource management in European transition economies: building a conceptual model on the case of Slovenia, International Journal of Human Resource Management, 16 (6), pp.882-906. 
Annex: 1 Dimensions and Elements of Strategic Human Resource Management Practice

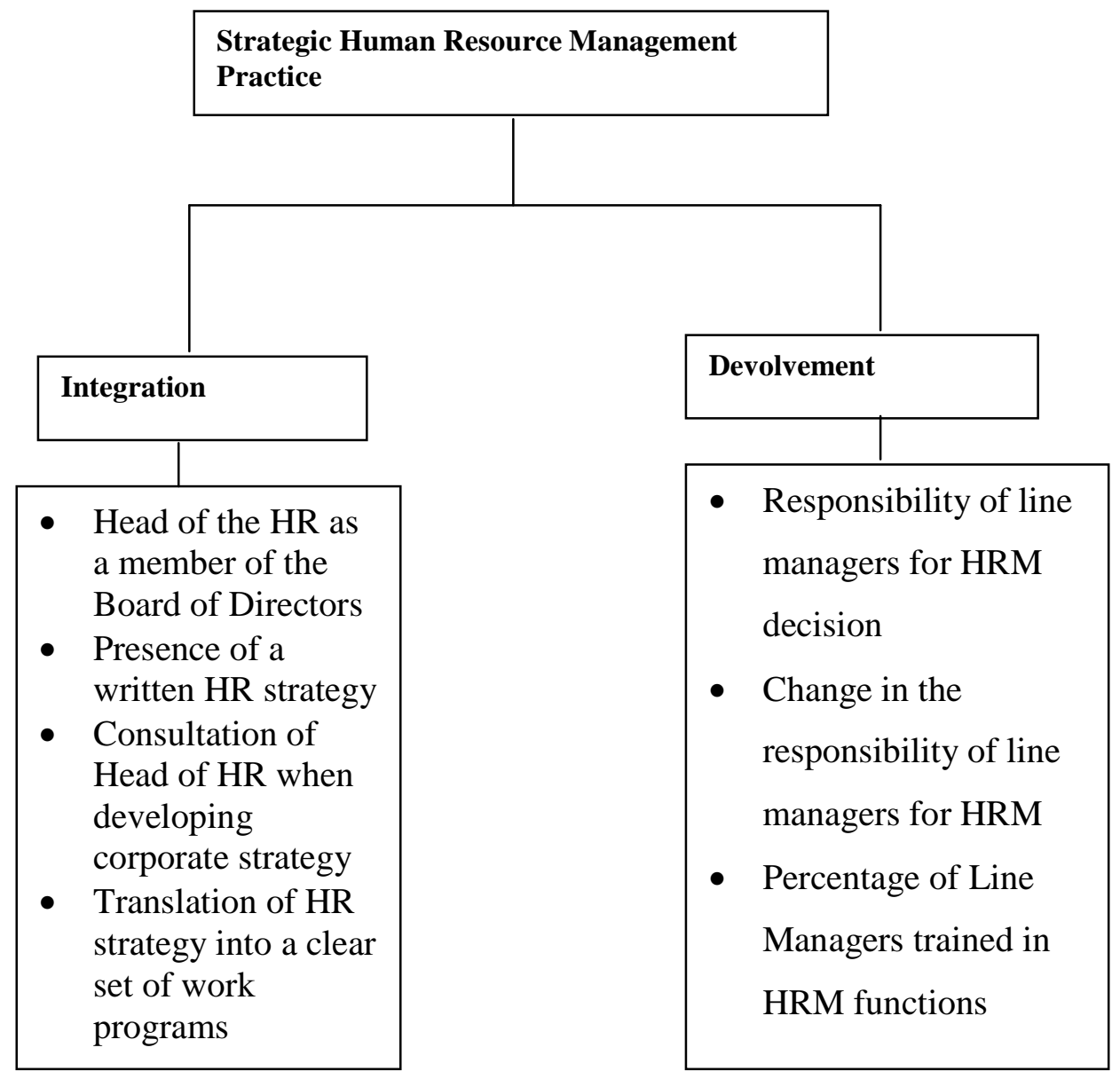

Source: Budhwar (2000) 